\title{
Gastrointestinal metabolism of phytoestrogens in lactating dairy cows fed silages with different botanical composition
}

\author{
K. M. Njåstad, ${ }^{* 1}$ S. A. Adler, ${ }^{\star} \dagger$ J. Hansen-Møller, $\ddagger^{2}$ E. Thuen, ${ }^{*}$ A.-M. Gustavsson, $\S$ and H. Steinshamn $\dagger^{3}$ \\ *Department of Animal and Aquacultural Sciences, Norwegian University of Life Sciences, PO Box 5003, 1432 Ås, Norway \\ †Bioforsk-Norwegian Institute of Agricultural and Environmental Research, Organic Food and Farming Division, Gunnars veg 6, 6630 Tingvoll, \\ Norway \\ ‡Department of Animal Science, Aarhus University, Blichers Allé 20, Postboks 50, 8830 Tjele, Denmark \\ $\S$ Department of Agricultural Research for Northern Sweden, Swedish University of Agricultural Sciences, 90183 Umeå, Sweden
}

\section{ABSTRACT}

Dietary phytoestrogens are metabolized or converted in the gastrointestinal tract of ruminants, only limited knowledge exists on the extent and location of this conversion in vivo. The objective of this study was to quantify the gastro-intestinal metabolism of phytoestrogens in lactating dairy cows fed silages with different botanical composition. Four lactating rumen cannulated Norwegian Red cattle were assigned to a 4 $\times 4$ Latin square with 1 cow per treatment period of 3 wk. The 4 treatment silages were prepared from grasslands with different botanical compositions: organically managed short-term timothy (Phleum pratense L.) and red clover (Trifolium pratense L.) ley (2 yr old: ORG$\mathrm{SG})$; organically managed long-term grassland with a high proportion of unsown species (6 yr old; ORG-LG); conventionally managed perennial ryegrass (Lolium perenne L.) ley (CON-PR); and conventionally managed timothy ley (CON-TI). The herbages were cut, wilted, and preserved with additive in round bales, fed as a mix of the first and third cut at $90 \%$ of ad libitum intake, and contributed to $70 \%$ of the total dry matter intake. Milk, feed, omasal digesta, urine, and feces were collected at the end of each period and analyzed for the concentrations of phytoestrogens by using a liquid chromatography-tandem mass spectrometry technique. Concentration of total isoflavones was highest in ORG$\mathrm{SG}$ and lowest in CON-TI silage, whereas the content of total lignans was highest in the grass silages. The isoflavones were extensively metabolized in the rumen on all diets, and the recovery of formononetin and daidzein in omasum, mainly as equol, averaged $0.11 \mathrm{mg} / \mathrm{mg}$. The apparent intestinal metabolism was less severe as, on average, $0.29 \mathrm{mg} / \mathrm{mg}$ of the omasal flow was recovered

Received April 4, 2014.

Accepted August 26, 2014.

${ }^{1}$ Current address: TINE Meieriet, Meierivegen 3, 5700 Voss, Norway.

${ }^{2}$ Current address: Cheminova A/S, PO Box 9, 7620 Lemvig, Denmark.

${ }^{3}$ Corresponding author: havard.steinshamn@bioforsk.no in feces. The plant lignans were also strongly degraded in the rumen. However, the flow of lignans to omasum and excretion in feces were, on average, 7.2- and 5.2fold higher, respectively, than the intake of the plant lignans matairesinol and secoisolariciresinol, known as precursors of mammalian lignans. Thus, excretion to milk could not be directly related to intake, implying that plant lignans other than matairesinol and secoisolariciresinol in forage are precursors for enterolactone production in the rumen and for its content in milk. Equol followed mainly the flow of large particles out of the rumen, whereas the mammalian lignans were distributed between phases proportional to dry matter flow. The main metabolism of phytoestrogens occurred in the rumen and the main route of excretion was through feces and urine, with only a small part being excreted in milk. The concentration of phytoestrogens in milk can be manipulated through intake but the intermediate transfer capacity to milk appears to be limited by saturation.

Key words: isoflavone, lignan, silage, recovery

\section{INTRODUCTION}

Phytoestrogens are a large group of plant-derived nonsteroidal compounds, with structural similarities to mammalian estrogen (17- $\beta$ estradiol). Phytoestrogens can bind to estrogen receptors and provide a weak estrogenic or antiestrogenic effect (Tham et al., 1998; Sirtori et al., 2005). Based on in vitro and in vivo studies the estrogenic potency of phytoestrogens has been estimated and is ranked as follows: estradiol $>$ coumestrol $>$ genistein and equol $>$ glycitein $>$ daidzein > formononetin, biochanin A (COT, 2003). A physiological effect of phytoestrogens was first shown in the 1940s when Bennetts et al. (1946) reported that sheep grazing on pastures containing red clover had fertility problems. The interest in phytoestrogens is currently linked to their possible favorable influence in human health, as related to cardiovascular disease, hormone-related cancers, osteoporosis, and menopausal 
symptoms, but also possible adverse health effects on infant development and processes influenced by sex steroids (Zung et al., 2001; Mendez et al., 2002; Tuohy, 2003), as endocrine-disrupting chemicals when lost to the wider environment from livestock urine and feces (Tucker et al., 2010), and on hormone-dependent cancers, depending on the timing of exposure (Bouker and Hilakivi-Clarke, 2000; De Assis and Hilakivi-Clarke, 2006).

Many ruminant feedstuffs may contain phytoestrogens, mainly isoflavones, coumestans, and lignans, which can be transferred to milk after digestion. Soybean [Glycine $\max$ (L.) Merrill] in concentrate supplements and grassland legumes, such as red clover (Trifolium pratense L.), are the most important sources (quantitatively) of isoflavones in ruminant feedstuffs (Mustonen et al., 2009; Třináctý et al., 2009). Lignans are primarily found in the cell walls of seeds from grain, legumes, and linseed (Linum usitatissimum L.) used in concentrate (Axelson et al., 1982; Cassidy et al., 2000; Petit et al., 2009). The third group, coumestans, of which coumestrol is the most important, are mainly found in legume seeds and sprouts of lucerne (Medicago sativa L.; Mazur, 1998).

Antignac et al. (2004) and Hoikkala et al. (2007) found 191 and $411 \mu \mathrm{g} / \mathrm{L}$ of equol in organically produced retail milk, respectively, whereas comparable milk from conventional production contained 36 and 62 $\mu \mathrm{g}$ of equol/L in the same studies, respectively. Concentrations of phytoestrogens in milk can be modulated by the concentration of phytoestrogens and their precursors in pasture (Andersen et al., 2009a; Adler et al., 2014), silage (Steinshamn et al., 2008; Andersen et al., 2009b; Mustonen et al., 2009), and concentrate (Petit et al., 2009; Třináctý et al., 2009). The mammalian isoflavonoid equol is the dominating phytoestrogen in milk from diets containing red clover (Steinshamn et al., 2008; Mustonen et al., 2009; Höjer et al., 2012), where concentrations in milk of up to $1,494 \mu \mathrm{g} / \mathrm{kg}$ have been reported (Höjer et al., 2012), and in diets with soybeans (Třináctý et al., 2009; $53 \mu \mathrm{g} / \mathrm{kg}$ of milk). Enterolactone is quantitatively the most important lignan in milk from diets containing white clover (Trifolium repens L.), lucerne or birdsfoot trefoil (Lotus corniculatus L., $226 \mu \mathrm{g} / \mathrm{kg}$ of milk; Höjer et al., 2012) in studies were legume species have been compared (Steinshamn et al., 2008; Andersen et al., 2009b; Höjer et al., 2012) and where linseed has been included in the diet (Petit and Gagnon, 2009; $24 \mu \mathrm{g} / \mathrm{kg}$ of milk).

Phytoestrogens are mainly present in plant material as glycosides, which are not active estrogenically (Miksicek, 1995). The major metabolic transformation of isoflavones in ruminants most likely occurs in the rumen by microbes that hydrolyze glycosides to aglycones (Nilsson et al., 1967; Dickinson et al., 1988). Biochanin A is demethylated to genistein and further metabolized via ring cleavage to $p$-ethyl phenol and organic acids without estrogenic effect (Nilsson et al., 1967; Batterham et al., 1971). Formononetin is mainly demethylated to daidzein (Lindner, 1967; Nilsson et al., 1967) and further to equol via hydrogenation and ring fission (Nilsson et al., 1967; Shutt and Braden, 1968; Batterham et al., 1971). Coumestrol does not seem to be metabolized in the rumen but provides an estrogenic effect itself. Isoflavones are mainly absorbed as aglycones in the rumen but also in the intestine, and are conjugated with glucuronic acid in the rumen gastrointestinal epithelium (Lundh, 1990). The major lignans found in plant food material are matairesinol and secoisolariciresinol (Axelson et al., 1982). The main site of metabolism of lignans in ruminants is, as for isoflavones, the rumen (Gagnon et al., 2009a). Microbes convert glycosides, as secoisolariciresinol-diglucoside, to aglycones that are further converted to mammalian lignans, enterodiol and enterolactone (Borriello et al., 1985). Absorption to portal blood occurs either in rumen or in the small intestine, where enterodiol may be further converted to enterolactone by colon microbes (Côrtes et al., 2008; Gagnon et al., 2009a). After absorption to the portal blood, the lignans are reconjugated with sulfate or glucuronic acid in the liver and excreted through the bile duct, where they may be deconjugated by bacterial enzymes and reabsorbed (Tham et al., 1998; Gagnon et al., 2009a). Some lignans reach the kidney and are excreted in the urine.

Although it is generally accepted that the main metabolism of phytoestrogens occurs in the rumen by rumen microbes, to our knowledge, no studies have examined and quantified the metabolism of phytoestrogens in lactating dairy cows in vivo. This knowledge is important if milk content of phytoestrogens is to be manipulated. Therefore, the objectives of the present study were to quantify the conversion of plant phytoestrogens into mammalian phytoestrogens in dairy cows fed different diets, and to evaluate their transfer to urine, feces, and milk.

\section{MATERIALS AND METHODS}

\section{Experimental Design and Animals}

The experiment was carried out at the Department of Animal and Aquacultural Sciences, Norwegian University of Life Sciences (Ås, Norway) with 4 rumencannulated lactating multiparous dairy cows. Adler et al. (2013) described the experiment in detail. In brief, the cows weighed on average $( \pm \mathrm{SD}) 631 \pm 35.5 \mathrm{~kg}$, were $118 \pm 40.9 \mathrm{~d}$ in lactation, and yielded $22.5 \pm 2.7$ 
$\mathrm{kg} / \mathrm{d}$ of milk at the beginning of the experiment. The cows were randomly allocated in a $4 \times 4$ Latin square, with 1 cow per treatment and period. Each experimental period lasted for $21 \mathrm{~d}$, including $14 \mathrm{~d}$ for adaptation and $7 \mathrm{~d}$ for sample collection. The cows were housed in a tiestall and milked twice daily at 0630 and 1530 h. The experiment was carried out in agreement with the laws and regulations controlling experiments on live animals in Norway under the surveillance of the Norwegian Animal Research Authority.

\section{Feeds and Feeding}

Silages were produced during summer 2009 from grasslands with different botanical composition: shortterm timothy (Phleum pratense L.) and red clover (Trifolium pratense L.) ley in its second production year (ORG-SG); long-term grassland with a high proportion of unsown species in its sixth production year (ORG-LG); perennial ryegrass (Lolium perenne L.) ley (CON-PR); and timothy ley (CON-TI). The ORG-SG and ORG-LG grasslands were managed organically according to standards for organic farming in Norway and the European Union (European Union, 2007) and were fertilized with fresh cattle slurry (20 to $25 \mathrm{Mg} / \mathrm{ha}$ ) in spring. The CON-PR and CON-TI grasslands received 88,92 , and $53 \mathrm{~kg}$ of $\mathrm{N} / \mathrm{ha}$ in spring, and after first and second cut, respectively. First cut was taken at early heading stage of timothy, the second and third at 5- and 8-wk intervals, respectively. The harvest was prewilted and ensiled in round bales applying an additive (GrasAAT N Lacto, ADDCON Nordic AS, Porsgrunn, Norway) at a rate of 4 to 5 $\mathrm{L} / \mathrm{Mg}$ of fresh weight. Botanical composition was manually recorded by sorting, before each harvest, by harvesting 6 squares, each of $0.5 \mathrm{~m}^{2}$, per field (Table
1). A 50:50 mixture on a DM basis of first and third harvesting was used for the treatment diets. Second cut could not be used because of drought and low yields. The concentrate contained organically produced barley $(933 \mathrm{~g} / \mathrm{kg}$ of DM), organically produced molasses (50 $\mathrm{g} / \mathrm{kg}$ of DM), and a mineral premix ( $17 \mathrm{~g} / \mathrm{kg}$ of DM). The mineral premix contained Ca $110 \mathrm{~g} / \mathrm{kg}, \mathrm{P} 65 \mathrm{~g} /$ $\mathrm{kg}, \mathrm{Mg} 90 \mathrm{~g} / \mathrm{kg}$, Na $95 \mathrm{~g} / \mathrm{kg}, \mathrm{Cl} 143 \mathrm{~g} / \mathrm{kg}, \mathrm{S} 9 \mathrm{~g} / \mathrm{kg}$, Fe $494 \mathrm{mg} / \mathrm{kg}$, Mn 3,001 mg/kg, Zn 4,001 mg/kg, Cu $900 \mathrm{mg} / \mathrm{kg}$, Co $21 \mathrm{mg} / \mathrm{kg}$, I $152 \mathrm{mg} / \mathrm{kg}$, and Se $60 \mathrm{mg} /$ kg (NORMIN, Hønefoss, Norway). The cows were fed individually by using automatic belt feeders 4 times per day, with $6 \mathrm{~h}$ between each feeding. Concentrate and silage were fed together at constant ratio of 30:70 on a DM basis throughout the experiment. The silage was fed ad libitum from d 1 to 11 and at $90 \%$ of ad libitum intake from d 12 to 21 . Feed intake was recorded daily and feed residues were collected from d 12 to 21 . Rumen content was exchanged between cows on the same treatment on $\mathrm{d} 1$ of the subsequent period to facilitate adaption to new silage.

\section{Triple Marker System}

A triple-marker technique (Faichney, 1975; Ahvenjärvi et al., 2000) was used to determine the digesta flow to the omasal canal, and the procedures used in the present study are described in detail by Adler et al. (2013). The indigestible neutral detergent fiber (iNDF) fraction was used as internal marker for large particles, and ytterbium acetate (YbAc) and chromium EDTA (CrEDTA) were used as external markers for small particles and liquid phase, respectively. Ytterbium acetate $(2.3 \mathrm{~g}$ of $\mathrm{Yb} / \mathrm{d})$ and CrEDTA $(2.4 \mathrm{~g}$ of $\mathrm{Cr} / \mathrm{d})$ were dissolved in tap water and infused directly into the rumen of each cow from d 8 to 20, using a peri-

Table 1. Grassland botanical composition (\% of total DM) for red clover-grass (ORG-SG), botanical diverse (ORG-LG), perennial ryegrass (CON-PR), and timothy (CON-TI) silages ${ }^{1}$

\begin{tabular}{|c|c|c|c|c|}
\hline \multirow[b]{2}{*}{ Species } & \multicolumn{4}{|c|}{ Silage } \\
\hline & ORG-SG & ORG-LG & CON-PR & $\mathrm{CON}-\mathrm{TI}$ \\
\hline \multicolumn{5}{|l|}{ Grasses } \\
\hline Phleum pratense L. & 42 & 18 & 0 & 96 \\
\hline Lolium perenne L. & 1 & 1 & 87 & 0 \\
\hline Festuca pratensis Huds. & 0 & 11 & 0 & 0 \\
\hline Poa pratensis $\mathrm{L}$. & 0 & 26 & 0 & 0 \\
\hline Other grasses & 9 & 7 & 0 & 0 \\
\hline \multicolumn{5}{|l|}{ Herbs } \\
\hline Trifolium pratense L. & 36 & 1 & 0 & 0 \\
\hline Trifolium repens $\mathrm{L}$. & 3 & 9 & 6 & 0 \\
\hline Taraxacum spp. & 0 & 10 & 0 & 0 \\
\hline Ranunculus repens L. & 1 & 9 & 0 & 0 \\
\hline Other herbs & 2 & 5 & 0 & 0 \\
\hline Dead material & 6 & 4 & 6 & 4 \\
\hline
\end{tabular}

${ }^{1}$ Data are extracted from the botanical composition data given in Table 1 in Adler et al. (2013). 
staltic pump (Cenco Instruments MIJ N.V., Breda, the Netherlands) with tubes to the rumen. Before infusion start, a dose equal to half the daily amount of both external markers was given to each cow to quickly reach equilibrium of the markers in the rumen.

\section{Sampling}

Feeds. Samples from each silage type (raw) and feed residues were collected daily from d 15 to 20 and stored frozen $\left(-20^{\circ} \mathrm{C}\right)$. At the end of each period, the 5 samples were mixed, pooled to one sample per silage, and prepared for analysis. Freeze-dried samples (Christ LCM-2 $\beta$ 1-16 lyophilizer and Christ LOC-1 $\mathrm{m} \alpha$ 1-4 lyophilizer, Martin Christ, Osterode am Harz, Germany; Hetosicc, Birkerød, Denmark) were ground on a hammer mill (grind size $1 \mathrm{~mm}$ if not otherwise stated) and analyzed for DM, ash, Kjeldahl-N, NDF, phytoestrogens, starch (grind size $0.5 \mathrm{~mm}$ ) and iNDF fraction (grind size $1.5 \mathrm{~mm}$ ). Samples of silages not dried were analyzed for DM, Kjeldahl-N, ammonium-N $\left(\mathrm{NH}_{4}-\mathrm{N}\right), \mathrm{pH}$, volatile acids, and ethanol. Loss of volatile compounds in silage during drying was corrected for by equations from the Nordic Feed Evaluation System (Åkerlind et al., 2011). Three samples of concentrate were collected in each period, pooled, stored frozen $\left(-20^{\circ} \mathrm{C}\right)$, and analyzed for DM, ash, Kjeldahl-N, NDF, starch, and phytoestrogens.

Markers and Omasal Digesta. Samples of infusing fluid were collected on d 12, 17, and 21 , and stored at $4^{\circ} \mathrm{C}$ until analyses. To determine digesta flow to the omasal canal, samples of omasal digesta were collected according to the technique developed by Huhtanen et al. (1997) and modified by Ahvenjärvi et al. (2000). Digesta $(500 \mathrm{~mL})$ were collected when leaving the reticulorumen and led to outside the rumen cannula through a plastic tube using a vacuum pump. Samples were collected 4 times daily on d 18 through 20 and distributed to cover each second hour during a 24-h period. Samples were pooled and stored at $-20^{\circ} \mathrm{C}$ until preparation. The digesta was divided into 3 different phases: large-particle phase $(\mathbf{L P})$, small-particle phase (SP), and fluid phase (FP), by filtering through a 100$\mu \mathrm{m}$ nylon filter and centrifuging at $10,000 \times g$ for 15 min at $5^{\circ} \mathrm{C}$. After preparation, the different phases were frozen $\left(-20^{\circ} \mathrm{C}\right)$ until freeze drying and milled (grind size $1.0 \mathrm{~mm}$ ). The 3 phases were analyzed for $\mathrm{Yb}, \mathrm{Cr}$, $\mathrm{DM}$, and phytoestrogens, and LP and SP were also analyzed for iNDF.

Feces and Urine. Feces were collected quantitatively from each cow 3 times per day over $3 \mathrm{~d}$ and stored at $4^{\circ} \mathrm{C}$ between collections. Ten percent of daily fecal production was pooled to 1 sample per collection period and stored at $-20^{\circ} \mathrm{C}$. Dry matter content was analyzed in raw material; DM, phytoestrogens, $\mathrm{Yb}, \mathrm{Cr}$ (milled, grind size $1.0 \mathrm{~mm}$ ) and iNDF (milled, grind size $1.5 \mathrm{~mm}$ ) were analyzed in freeze-dried material.

The cows were fitted with urine funnels that led to collection buckets. Urine was collected from the urine funnels of each cow 3 times daily in $3 \mathrm{~d}$, and $0.5 \mathrm{~L}$ of $10 \% \mathrm{H}_{2} \mathrm{SO}_{4}$ was added to collection buckets before sampling to ensure a $\mathrm{pH}<4.0$. Ten percent of daily urine production was pooled to 1 sample per collection period. Urine was analyzed for $\mathrm{Cr}$ and phytoestrogens.

Milk. Milk yield was weighed at each milking. Aliquot milk samples were taken on $3 \mathrm{~d}$ in the sample collection period, on d 18 through 20, pooled and stored at 0 to $2^{\circ} \mathrm{C}$. Pooled samples were stored at $-20^{\circ} \mathrm{C}$ until analysis for the content of phytoestrogens.

\section{Chemical Analysis}

Feed. Dry matter was analyzed by drying at $105^{\circ} \mathrm{C}$ until constant weight. Ash was analyzed by flame combustion by heating to $550^{\circ} \mathrm{C}, 4 \mathrm{~h}$ or overnight. Kjeldahl-N was analyzed following method number 984.13 (AOAC, 1990), with the following modifications: digestion with $15 \mathrm{~mL}$ of $\mathrm{H}_{2} \mathrm{SO}_{4}, 3.5 \mathrm{~g}$ of $\mathrm{K}_{2} \mathrm{SO}_{4}$, and $0.4 \mathrm{~g}$ of $\mathrm{CuSO}_{4}$, boiled for $45 \mathrm{~min}$ at $420^{\circ} \mathrm{C}$ on a heating block, and $250 \mathrm{~mL}$ of distilled water added after cooling. Content of NDF was determined according to Mertens (2002), using sodium sulfite and $\alpha$-amylase without ash correction. Content of starch was determined by the method described in AACC (2000) except that heatstable $\alpha$-amylase was used instead of pullulanase. The silages were analyzed for lactic acid, acetic acid, butyric acid, formic acid, propionic acid, and ethanol by HPLC using a VA 300/7.8 Nucleogel Ion 300 OA column (Machery-Nagel, Düren, Germany) at $50^{\circ} \mathrm{C}$ (mobile phase, $0.010 \mathrm{M} \mathrm{H}_{2} \mathrm{SO}_{4}$ at $0.6 \mathrm{~mL} / \mathrm{min}$ ) with a UV spectrophotometric detector for lactic acid and a refractive index detector for other acids and ethanol, ammonium$\mathrm{N}$ with MAN-TECH PC-titrate (Guelph, ON, Canada) using an Orion ion analyzer 901, and $\mathrm{pH}$ with a Termo Orion 420A + pH-meter with Orion 9107BN electrode (Thermo Scientific, Beverly, MA).

Markers. Ytterbium and Cr were determined using an atomic absorption spectrophotometer (GBC SavantAA Ser. No A6990, GBC Scientific Equipment, Hampshire, IL). In marker infusing fluid, $50 \mu \mathrm{L}$ of $\mathrm{H}_{2} \mathrm{SO}_{4}$ was added before analysis. In omasal digesta and feces, $200 \mathrm{mg}$ of sample material was dissolved in scintillation glasses, boiled for $30 \mathrm{~min}$, and diluted to $21.5 \mathrm{~mL}$ before analysis of $\mathrm{Yb}$, and $100 \mathrm{mg}$ of sample material was combusted and dissolved with $0.75 \mathrm{~mL}$ of $\mathrm{H}_{3} \mathrm{PO}_{4}$ and $1 \mathrm{~mL}$ of $\mathrm{KBrO}_{3}$ in scintillation glasses, boiled for $10 \mathrm{~min}$, and diluted to $21.5 \mathrm{~mL}$ before analysis of $\mathrm{Cr}$. Indigestible NDF in freeze-dried samples of silages, 
concentrates, omasal digesta, and feces was determined by $288 \mathrm{~h}$ in sacco incubations in nylon bags $(17 \mu \mathrm{m})$ in 2 cows. After incubation, the bags were washed in cold water in a laundry machine, extracted in NDF solution at $100^{\circ} \mathrm{C}$ for $1 \mathrm{~h}$, and dried at $60^{\circ} \mathrm{C}$.

Phytoestrogens. Phytoestrogens were analyzed according to the method described by Steinshamn et al. (2008) at the Department of Animal Science, Faculty of Science and Technology, Aarhus University (Aarhus, Denmark). Feed (silages, feed residues, and concentrate), omasal digesta, and feces were extracted with ethanol and acetate buffer ( $\mathrm{pH}$ 5.0), and then incubated with Cellulase Onozuka R-10 from Trichoderma viride (Merck, Darmstadt, Germany) at ambient temperature overnight. Urine was centrifuged at $3,000 \times g$ for 10 min, and then a sample $(500 \mu \mathrm{L})$ was deproteinized by mixing with $500 \mu \mathrm{L}$ of acetate buffer (pH 5.2). Conjugates of phytoestrogens were cleaved by incubation with $5 \mu \mathrm{L}$ of $\beta$-glucuronidase and sulfates from Helix pomatia type H2 (Sigma-Aldrich, St. Louis, MO) at $37^{\circ} \mathrm{C}$ for $1 \mathrm{~h}$. Milk was deproteinized and defatted using acetate buffer ( $\mathrm{pH}$ 5.2), heptane, and acetone. Acetonewater phase was evaporated to dryness and residues redissolved in water. Conjugates of phytoestrogens were cleaved by incubation with $\beta$-glucuronidase and sulfates from Helix pomatia type H2 (Sigma-Aldrich) at $40^{\circ} \mathrm{C}$ for $4 \mathrm{~h}$.

Secoisolariciresinol, matairesinol, enterodiol, daidzein, enterolactone, equol, genistein, coumestrol, formononetin, prunetin, and biochanin A were analyzed using the liquid chromatography-tandem mass spectrometry (LC-MS/MS) technique, where feed, omasal digesta, and feces were analyzed using an external standard. Urine and milk were analyzed with standard addition (of known quantities of the analyzed phytoestrogens). This method for analysis of the content of phytoestrogen in urine has not been validated and the results must be treated with caution.

\section{Calculations}

Feed intake was calculated as the difference between DM offered and DM residue. Crude protein was calculated as Kjeldahl- $\mathrm{N} \times 6.25$. Digesta flow to the omasum was calculated using the 3-marker system according to the reconstitution technique of Faichney (1975) and Armentano and Russell (1985). The amount of concentrate in the feed residues was estimated using starch content in the feed residue samples. The marker recoveries for CON-PR were low compared with the mean of the other diets in all periods (CON-PR as a proportion of the mean of the other diets: iNDF, $0.71 ; \mathrm{Yb}, 0.79$; Cr, 0.78; Adler et al., 2013). Further, the collection of feces DM for CON-PR was 0.71 of the mean of the other diets. Therefore, the amount of feces for CON-PR was adjusted to give the same recovery for $\mathrm{Cr}$ as for the mean of the other diets in each period. In period 1 , fecal amounts were divided by 0.671 , in period 2 by 0.912 , in period 3 by 0.727 , and in period 4 by 0.804 . This resulted in a lower (0.93) estimate of total-tract digestibility for CON-PR.

The sum of phytoestrogens (concentrations and amounts) with similar metabolic pathways was calculated in different compartments (feed, digesta, urine, feces, milk): biochanin A + genistein (BG), formononetin + daidzein + the metabolite equol (FDE), and the lignans secoisolariciresinol + matairesinol + the metabolites enterodiol and enterolactone (SMEE). Apparent recovery of BG, FDE, and SMME were calculated as (1) from feed to omasum = flow to omasum/ feed intake; (2) from feed to milk = excreted in milk/ feed intake; omasum to feces $=$ excreted in feces/flow to omasum; omasum to milk = excreted in milk/flow to omasum.

\section{Statistical Analysis}

Data were analyzed using the Mixed procedure in SAS (SAS Institute, 2009) with the following model:

$$
\mathrm{Y}_{\mathrm{ijk}}=\mu+\alpha_{\mathrm{i}}+\beta_{\mathrm{j}}+\mathrm{c}_{\mathrm{k}}+\mathrm{e}_{\mathrm{ijk}},
$$

where $\mathrm{Y}$ is the dependent variable, $\mu$ is the overall mean, $\alpha$ is the fixed effect of period i (1 through 4$)$, $\beta$ is the fixed effect of treatment $\mathrm{j}$ (1 through 4$)$, c is the random effect of cow $\mathrm{k}$ (1 through 4$)$, and e is the error term. Analyses of phytoestrogen concentration in silages were done without $\mathrm{k}$ in the model. For the analysis of the flow of phytoestrogens to the omasal canal, phase (LP, SP, and FP) and its interaction with diet were included as fixed effects. Tukey's multiple comparison test was used to determine significant $(P<$ $0.05)$ difference between treatments.

If the content of a phytoestrogen was below the limit of detection, half the detection limit was used so that the statistical analysis could be run. If the residual variance was not constant, the variables were transformed logarithmically (daidzein and equol in the analysis of omasal flow of phytoestrogens in particle fractions). Tests of significance were first made on the transformed scale and then back-transformed to the original scale for presentation. Predicted means on the transformed scale, when back-transformed, give predicted medians on the original scale. Because standard errors are not constant for comparison on the original scale, the results for the transformed variables are presented as least squares means with pooled standard errors based on the original values. 


\section{RESULTS}

\section{Silage Botanical Composition and Chemical Characteristics}

The ORG-SG had high proportions of red clover and timothy (Table 1). The ORG-LG silage had higher proportions of the grasses meadow fescue (Festuca pratensis Huds., 0.11 vs. 0.0 ) and smooth meadowgrass (Poa pratensis L., 0.26 vs. 0.0 ) and of the herbs dandelion (Taraxacum spp., 0.10 vs. 0.0) and white clover (0.09 vs. 0.03) than ORG-SG. The grass silages CON-PR and CON-TI were dominated by perennial ryegrass and timothy, respectively.

The silage DM content was higher in ORG-SG and CON-TI than in ORG-LG and CON-PR; and CON-TI had $25 \%$ higher NDF and $21 \%$ lower CP concentration than the other silages (Table 2). Fermentation quality was generally good in all silages. The degree of fermentation was lower in ORG-SG and CON-TI than in the other 2 silages as indicated by lower concentrations of silage fermentation acids and ethanol, reflecting differences in DM content.

\section{Feed Intake, Omasal Flow, and Feces, Urine, and Milk Outputs}

We detected no significant effect of diet on DM intake (Table 3). However, silage intake was numerically lower $(0.6 \mathrm{~kg} / \mathrm{d})$ on CON-TI than on the other diets, which was reflected in a $10 \%$ lower $(P<0.001)$ milk yield in cows fed CON-TI than for the other diets. We found no difference in DM flow to the omasum. The excretion of urine was $20 \%$ lower $(P<0.05)$ for ORG-SG than for CON-PR.

\section{Concentrations of Phytoestrogens in Feed, Digesta, Feces, Urine, and Milk}

Silage. Silage concentration of total isoflavones was higher than of total lignans and coumestrol for ORGSG, ORG-LG, and CON-PR, whereas for CON-TI, the concentration of total lignans was higher than those of total isoflavones and coumestrol (Table 4). The ORGSG silage had concentrations of all isoflavones 35 to 98 times higher $(P<0.001)$ than those of the other silages. The content of the lignan matairesinol was, on average, 5 times higher $(P<0.001)$ in $\mathrm{CON}-\mathrm{TI}$ than in the other silages, whereas the pure grass silages $(\mathrm{CON}-\mathrm{PR}$ and CON-TI) had 2 times higher $(P<0.001)$ content of secoisolariciresinol than the clover-containing silages. The content of coumestrol was higher $(P<0.001)$ in the clover-containing silages than in the grass-based silages.

Omasal Digesta and Feces. The cows fed ORG-SG had 11 to 65 times higher $(P<0.001)$ concentrations of all isoflavones in the omasal digesta compared with the cows fed other diets, and ORG-SG and ORG-LG resulted in 2 times higher $(P<0.001)$ digesta contents of coumestrol than the grass-based diets (Table 5). In feces, we detected no effect of diet on the concentrations of biochanin A and genistein $(P>0.05)$, but for formononetin, equol, daidzein, and prunetin, the effect of ORG-SG was still present, yielding 11 to 66 times higher $(P<0.001)$ concentrations than the other diets. Feces concentrations of coumestrol were higher $(P<$ 0.001 ) for the diets with herbs than on the pure grass silage diets. Diet had no effect on the omasal digesta content of lignans, but the content of enterolactone $(P$ $<0.05)$ and enterodiol $(P<0.01)$ in feces were 47 and $60 \%$ higher, respectively, for the grass diets than for the clover-containing diets.

Table 2. Chemical composition of the concentrate and experimental silages based on red clover-grass (ORG-SG), botanical diverse (ORG-LG), perennial ryegrass (CON-PR), or timothy silage (CON-TI), silage fermentation products, and $\mathrm{pH}$

\begin{tabular}{|c|c|c|c|c|c|}
\hline Item & \multicolumn{4}{|c|}{ Silage } & Concentrate \\
\hline $\mathrm{DM}, \mathrm{g} / \mathrm{kg}$ & $325 \pm 4.1$ & $272 \pm 4.4$ & $293 \pm 6.3$ & $320 \pm 19.6$ & $869 \pm 2.2$ \\
\hline \multicolumn{6}{|l|}{ Chemical composition, $\mathrm{g} / \mathrm{kg}$ of DM } \\
\hline $\mathrm{OM}$ & $914 \pm 2.7$ & $895 \pm 28.2$ & $906 \pm 2.6$ & $925 \pm 2.4$ & $952 \pm 4.0$ \\
\hline NDF & $428 \pm 8.4$ & $434 \pm 9.4$ & $422 \pm 11.6$ & $534 \pm 11.6$ & $173 \pm 4.1$ \\
\hline $\mathrm{CP}$ & $146 \pm 8.9$ & $135 \pm 1.9$ & $153 \pm 6.4$ & $114 \pm 2.3$ & $127 \pm 1.2$ \\
\hline \multicolumn{6}{|c|}{ Silage fermentation products, $\mathrm{g} / \mathrm{kg}$ of $\mathrm{DM}$} \\
\hline Silage acids ${ }^{2}$ & $\begin{array}{r}45 \pm 2.2 \\
14.8+21\end{array}$ & $81 \pm 2.3$ & $79 \pm 1.32$ & $45 \pm 12.0$ & - \\
\hline Ethanol & $14.8 \pm 2.1$ & $18.6 \pm 2.7$ & $19.7 \pm 2.7$ & $16.1 \pm 2.1$ & - \\
\hline Ammonium-N, $\mathrm{g} / \mathrm{kg}$ of $\mathrm{N}$ & $61 \pm 3.0$ & $82 \pm 7.1$ & $83 \pm 7.5$ & $96 \pm 11.2$ & - \\
\hline $\mathrm{pH}$ & $4.5 \pm 0.0$ & $4.4 \pm 0.06$ & $4.5 \pm 0.05$ & $4.7 \pm 0.17$ & - \\
\hline
\end{tabular}

${ }^{1}$ Values are means $\pm \mathrm{SD}(\mathrm{n}=4)$. Data on silage concentrations of DM, NDF, CP, starch, acids, ethanol, ammonium, and $\mathrm{pH}$ of silage are extracted from Table 2 in Adler et al. (2013).

${ }^{2}$ Sum of lactic, acetic, butyric, formic, and propionic acids. 
Table 3. Feed intake, omasal flow, fecal and urine output, and milk yield in dairy cows fed different silages $(\mathrm{n}=4)$ based on red clover-grass (ORG-SG), botanical diverse (ORG-LG), perennial ryegrass (CON-PR), or timothy (CON-TI $)^{1}$

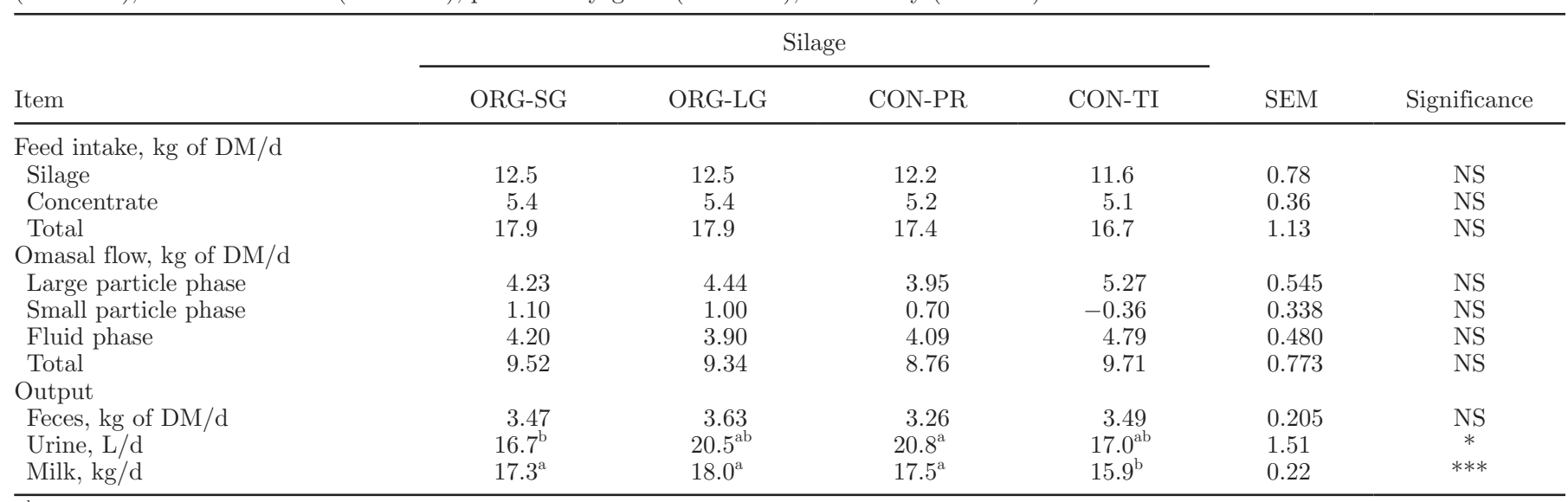

$\overline{\mathrm{a}, \mathrm{b}}$ Means in the same row with different superscript differ (Tukey test, $P<0.05$ ).

${ }^{1}$ Data on silage and concentrate DM intake are extracted from Table 3 in Adler et al. (2013).

${ }^{*} P<0.05 ;{ }^{* * *} P<0.001$. Statistical significance was judged as $P<0.05$.

Urine. Urine from cows offered CON-TI had higher $(P<0.05)$ contents of biochanin $\mathrm{A}$, genistein, formononetin, and prunetin than urine from ORG-LG and CON-PR and higher content of formononetin than urine from ORG-SG (Table 6). Equol concentration in urine from cows fed ORG-SG was, on average, 5,000 times higher $(P<0.001)$ for than in urine from cows fed the other diets. Urine from cows fed ORG-SG had the lowest $(P<0.001)$ content of the mammalian lignans enterolactone and enterodiol. We detected no difference in the content of enterolactone between the other diets, whereas for enterodiol all diets differed, with urine from CON-PR having the highest concentration. Urine concentration of coumestrol was not affected by diet.
Milk. In milk, the highest $(P<0.001)$ concentrations of all isoflavones, except prunetin $(P>0.05)$, were found in cows fed ORG-SG (Table 6). Equol was the most important isoflavone quantitatively on all diets, and concentration of equol was approximately 9 , 35, and 114 times higher in milk from ORG-SG than in milk from ORG-LG, CON-PR, and CON-TI, respectively. Cows fed CON-TI had higher milk content of enterolactone than cows fed ORG-SG. Otherwise, we found no effects of diet on the milk content of lignans. Cows fed ORG-SG (462 vs. $22.9 \mu \mathrm{g} / \mathrm{L}$ ) and ORG-LG $(58.2$ vs. $45.1 \mu \mathrm{g} / \mathrm{L})$ produced milk with higher concentration of isoflavones than lignans, whereas CON-PR $(27.9$ vs. $19.8 \mu \mathrm{g} / \mathrm{L})$ and $\mathrm{CON}-\mathrm{TI}(53.6$ vs. $8.7 \mu \mathrm{g} / \mathrm{L})$

Table 4. Concentrations of phytoestrogens in experimental silages $(\mathrm{n}=4)$ based on red clover-grass (ORG-SG), botanical diverse (ORG-LG), perennial ryegrass $(\mathrm{CON}-\mathrm{PR})$, or timothy $(\mathrm{CON}-\mathrm{TI})$ silage and concentrate $(\mathrm{mean} \pm \mathrm{SD} ; \mathrm{n}=4)$

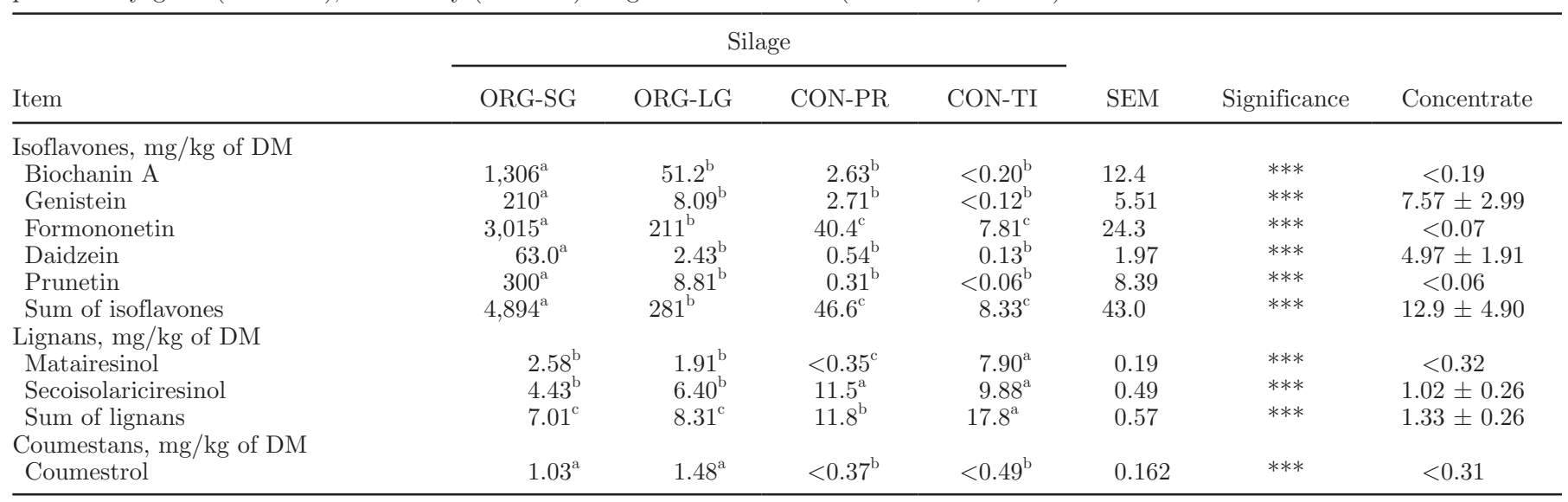

${ }^{\mathrm{a}-\mathrm{c}}$ Means in the same row with different superscripts are significantly different (Tukey test, $P<0.05$ ).

*** $P<0.001$. Statistical significance was judged as $P<0.05$. 


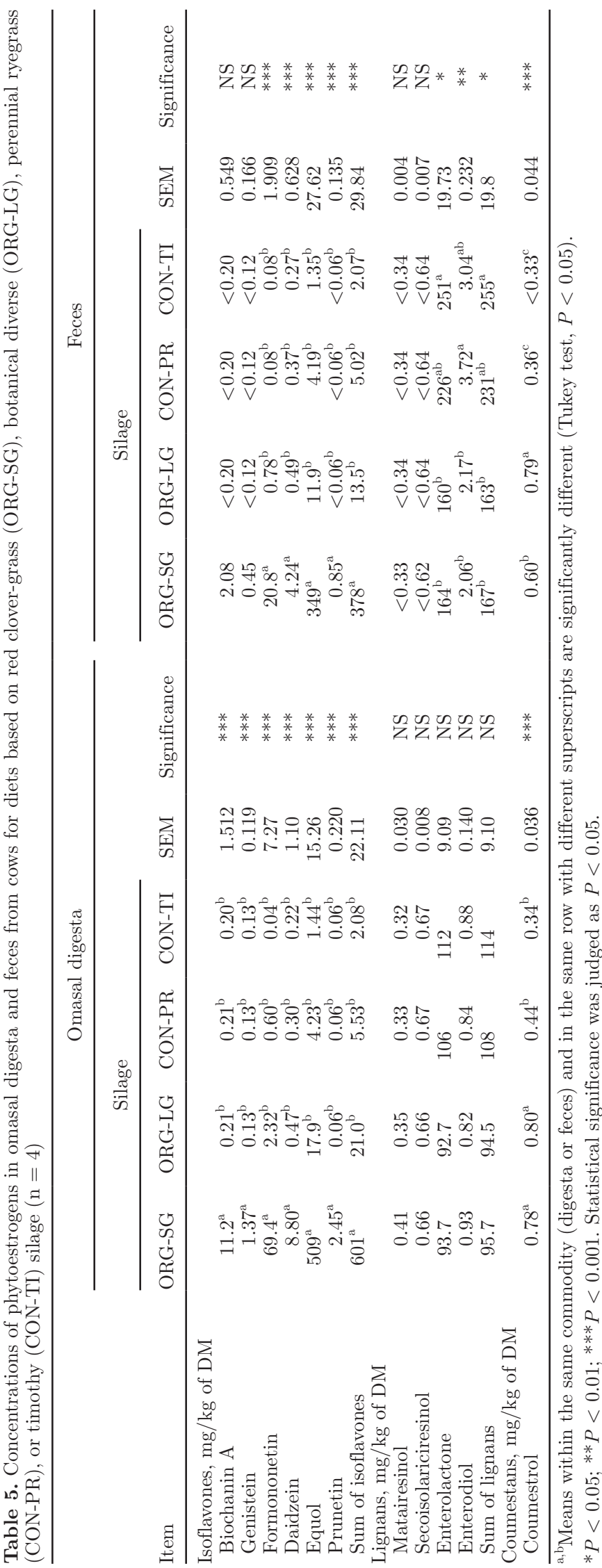

resulted in higher concentrations of lignans than isoflavones. Coumestrol was not detectable in milk.

\section{Distribution of Phytoestrogens in Different Omasal Digesta Phases}

The DM flow in digesta to the omasal canal followed mainly LP and FP, with the average proportion of DM passing daily being $0.48,0.07$, and 0.45 for LP, SP, and FP, respectively (Table 3). Several phytoestrogens were not detectable in omasal digesta phases, and therefore only omasal flows of the phytoestrogens detectable in all diets and phases are presented (Table 7). Equol followed mainly LP but a large part also followed SP. On average, $82 \%$ of equol was found in LP and only $7 \%$ in FP. The flow of daidzein differed from equol by resembling the DM distribution between phases on ORG-LG and CON-TI, whereas most of the daidzein followed the FP on ORG-SG. The distribution of the mammalian lignans between omasal phases was not affected by diet and was, to a large extent, similar to the distribution of DM.

\section{Metabolism of Phytoestrogens}

Biochanin A and Genistein. For all diets, most of the intake of biochanin A and genistein was metabolized in the reticulo-rumen, and only between 4.0 and $82 \mu \mathrm{g} / \mathrm{mg}$ of the total intake was recovered in the omasum (Table 8). The remainder, passing the omasum, was also strongly metabolized, because between 98 and $285 \mu \mathrm{g} / \mathrm{mg}$ of the omasal flow was found in feces and only 0.005 to $0.7 \mu \mathrm{g} / \mathrm{mg}$ was recovered in milk. We do not present the figures for urine excretion because the recovery was poor. However, the results indicate that between 70 and $90 \%$ of biochanin A and genistein passing the omasum were metabolized to other intermediary compounds or in the digestive tract. The apparent recovery of biochanin A and genistein from omasum to feces $(P<0.05)$ and from omasum to milk $(P<0.01)$ were lower for ORG-SG than for the other diets. The proportion recovered in milk from feed was similar on ORG-SG and CON-TI, but lower than on ORG-LG and $\mathrm{CON}-\mathrm{ORG}$.

Formononetin and Daidzein. Although less extensive, the metabolism of formononetin and daidzein followed the same pattern as for biochanin A and genistein, as most of the intake was metabolized in the reticulo-rumen to unidentified compounds or was absorbed (Table 9). Between 7 and $15 \%$ of the intake was recovered in the omasum as the sum of formononetin, daidzein, and their metabolite equol (FDE; Table 9). The further metabolism of FDE in the digestive tract was much less extensive than for biochanin A and ge- 
Table 6. Concentrations of phytoestrogens in urine and milk from cows fed diets based on red-clover (ORG-SG), botanical diverse (ORG-LG), perennial ryegrass (CON-PR), or timothy $(\mathrm{CON}-\mathrm{TI})$ silage $(\mathrm{n}=4)$

\begin{tabular}{|c|c|c|c|c|c|c|c|c|c|c|c|c|}
\hline \multirow[b]{3}{*}{ Item } & \multicolumn{6}{|c|}{ Urine } & \multicolumn{6}{|c|}{ Milk } \\
\hline & \multicolumn{4}{|c|}{ Silage } & \multirow[b]{2}{*}{ SEM } & \multirow[b]{2}{*}{ Significance } & \multicolumn{4}{|c|}{ Silage } & \multirow[b]{2}{*}{ SEM } & \multirow[b]{2}{*}{ Significance } \\
\hline & ORG-SG & ORG-LG & CON-PR & CON-TI & & & ORG-SG & ORG-LG & CON-PR & CON-TI & & \\
\hline \multicolumn{13}{|l|}{ Isoflavones, $\mu \mathrm{g} / \mathrm{L}$} \\
\hline Biochanin A & $16.0^{\mathrm{ab}}$ & $7.0^{\mathrm{b}}$ & $4.20^{\mathrm{b}}$ & $169.6^{\mathrm{a}}$ & 36.67 & * & $1.69^{\mathrm{a}}$ & $0.35^{\mathrm{b}}$ & $0.17^{\mathrm{b}}$ & $0.11^{\mathrm{b}}$ & 0.160 & $* * *$ \\
\hline Genistein & $10.0^{\mathrm{ab}}$ & $8.71^{\mathrm{ab}}$ & $5.94^{\mathrm{b}}$ & $17.7^{\mathrm{a}}$ & 2.40 & $*$ & $3.31^{\mathrm{a}}$ & $2.44^{\mathrm{b}}$ & $2.50^{\mathrm{ab}}$ & $1.68^{\mathrm{b}}$ & 0.189 & $* *$ \\
\hline Formononetin & $55.6^{\mathrm{b}}$ & $40.0^{\mathrm{b}}$ & $11.7^{\mathrm{b}}$ & $806^{\mathrm{a}}$ & 157.5 & $*$ & $8.20^{\mathrm{a}}$ & $2.80^{\mathrm{b}}$ & $2.33^{\mathrm{b}}$ & $1.63^{\mathrm{b}}$ & 0.548 & $* * *$ \\
\hline Daidzein & 115 & 65.6 & 28.7 & 126 & 25.9 & NS & $4.69^{\mathrm{a}}$ & $1.67^{\mathrm{b}}$ & $1.28^{\mathrm{b}}$ & $0.95^{\mathrm{b}}$ & 0.247 & *** \\
\hline Equol & $27,276^{\mathrm{a}}$ & $5,218^{\mathrm{b}}$ & $246^{\mathrm{b}}$ & $52.1^{\mathrm{b}}$ & 3,972 & $* * *$ & $443^{\mathrm{a}}$ & $50.1^{\mathrm{b}}$ & $12.8^{\mathrm{b}}$ & $3.90^{\mathrm{b}}$ & 28.30 & *** \\
\hline Prunetin & $3.65^{\mathrm{ab}}$ & $1.51^{\mathrm{b}}$ & $0.83^{\mathrm{b}}$ & $13.6^{\mathrm{a}}$ & 2.65 & $*$ & 1.01 & 0.73 & 0.67 & 0.35 & 0.149 & NS \\
\hline Sum of isoflavones & $27,487^{\mathrm{a}}$ & $5,352^{\mathrm{b}}$ & $301^{\mathrm{b}}$ & $1,191^{\mathrm{b}}$ & 2,836 & $* *$ & $462^{\mathrm{a}}$ & $58.2^{\mathrm{b}}$ & $19.8^{\mathrm{b}}$ & $8.73^{\mathrm{b}}$ & 28.4 & $* * *$ \\
\hline \multicolumn{13}{|l|}{ Lignans, $\mu \mathrm{g} / \mathrm{L}$} \\
\hline Matairesinol & 21.3 & 1.87 & 4.89 & 2.95 & 7.99 & NS & 0.95 & 1.13 & 0.91 & 1.16 & 0.220 & NS \\
\hline Secoisolariciresinol & 0.79 & 0.91 & 0.63 & 0.48 & 0.244 & NS & 3.66 & 4.25 & 3.24 & 5.30 & 1.027 & NS \\
\hline Enterolactone & $231^{\mathrm{b}}$ & $5,358^{\mathrm{a}}$ & $5,942^{\mathrm{a}}$ & $5,954^{\mathrm{a}}$ & 423.3 & $* * *$ & $17.9^{\mathrm{b}}$ & $39.3^{\text {ab }}$ & $23.3^{\text {ab }}$ & $46.7^{\mathrm{a}}$ & 6.94 & $*$ \\
\hline Enterodiol & $14.5^{\mathrm{d}}$ & $65.0^{\mathrm{b}}$ & $80.1^{\mathrm{a}}$ & $52.6^{\mathrm{c}}$ & 5.61 & $* * *$ & 0.47 & 0.41 & 0.47 & 0.48 & 0.134 & NS \\
\hline Sum of lignans & $268^{\mathrm{b}}$ & $5,426^{\mathrm{a}}$ & $6,027^{\mathrm{a}}$ & $6,010^{\mathrm{a}}$ & 428 & *** & $22.9^{\mathrm{b}}$ & $45.1^{\text {ab }}$ & $27.9^{\mathrm{b}}$ & $53.6^{\mathrm{a}}$ & 7.54 & $*$ \\
\hline \multicolumn{13}{|l|}{ Coumestans, $\mu \mathrm{g} / \mathrm{L}$} \\
\hline Coumestrol & 10.0 & 11.5 & 3.19 & 5.95 & 1.98 & NS & $\mathrm{ND}^{1}$ & ND & ND & ND & & \\
\hline
\end{tabular}

${ }^{\mathrm{a}-\mathrm{C}}$ Means within the same commodity (urine or milk) and in the same row with different superscripts are significantly different (Tukey test, $P<0.05$ )

Not detected.

$\quad * P<0.05 ;{ }^{* *} P<0.01 ;{ }^{* * *} P<0.001$. Statistical significance was judged as $P<0.05$. 
Table 7. Daily passage (mg/d) and proportion of daily passage of phytoestrogens to the omasum in large particle phase (LP), small particle phase (SP), and fluid phase (FP) in dairy cows fed diets based on red clover-grass (ORG-SG), botanical diverse (ORG-LG), perennial ryegrass diet $(\mathrm{CON}-\mathrm{PR})$, or timothy $(\mathrm{CON}-\mathrm{TI})$ silage $(\mathrm{n}=4)$

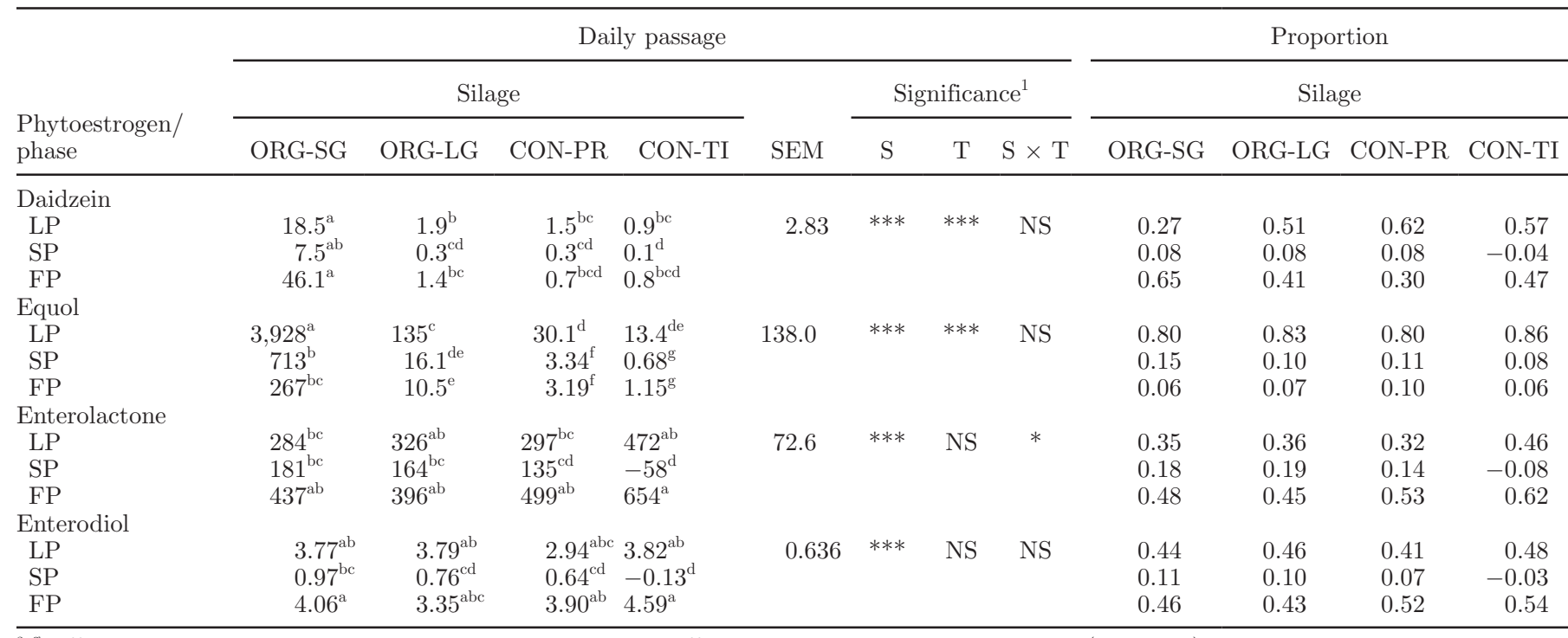

${ }^{a-g}$ Different letters within phytoestrogen indicate statistical difference within treatment and phase $(P<0.05)$.

${ }^{1} \mathrm{~T}=$ phase; $\mathrm{S}=$ silage.

${ }^{*} P<0.05 ; * * * P<0.001$. Statistical significance was judged as $P<0.05$.

nistein, and between 24 and $34 \%$ entering the omasum was excreted in the feces. Between 1.4 and $6.1 \mu \mathrm{g} / \mathrm{mg}$ of FDE entering the omasum was apparently recovered in milk, whereas the apparent recovery from feed to milk ranged between 0.2 and $0.8 \mu \mathrm{g} / \mathrm{mg}$. Less than $1.5 \%$ of the total excretion was through milk. Excretion to feces was higher $(P<0.001)$ for ORG-SG than for the other diets, and more than $70 \%$ of the total excretion was through feces. The proportions transferred from feed and omasum to feces did not differ between diets, but the apparent recovery from omasum to milk decreased with increasing intake and was lower $(P<0.05)$ for ORG-SG than for CON-PR.
Lignans. The metabolism of lignans differed from the metabolism of isoflavones because more lignans (SMEE) passed to the omasum than the intake of secoisolariciresinol and matairesinol, indicating an apparently low metabolism in the reticulo-rumen (Table 10). On average, 7 times more SMEE left the omasum and 5 times more SMEE was excreted in feces than the intake of secoisolariciresinol and matairesinol. On average, $74 \%$ of SMEE passing the omasum was transferred to the feces and the average recovered in milk from omasum was only $0.6 \mu \mathrm{g} / \mathrm{mg}$. The urine data indicate that feces were the major route of excretion of SMEE ( $>84 \%$ of the total excretion of SMEE).

Table 8. Metabolism of biochanin A and genistein (BG = biochanin A + genistein) in dairy cows fed diets based on red clover-grass (ORG-SG), botanical diverse (ORG-LG), perennial ryegrass (CON-PR) or timothy (CON-TI) silage $(\mathrm{n}=4)$

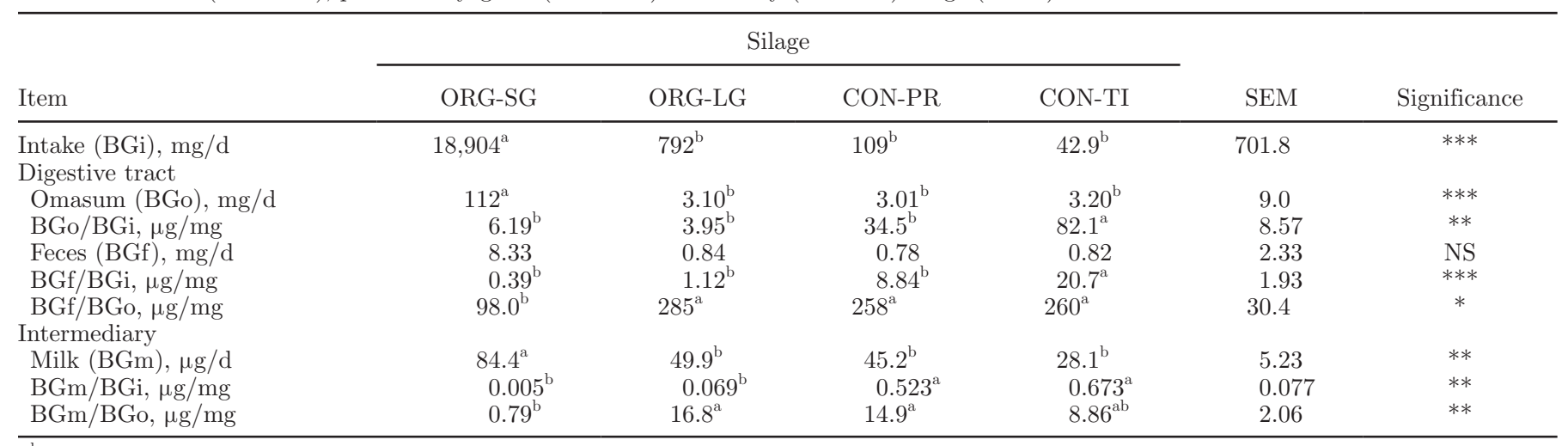

$\overline{\mathrm{a}, \mathrm{b}}$ Different letters within phytoestrogen indicate statistical difference within treatment and phase $(P<0.05)$.

${ }^{*} P<0.05 ;{ }^{* *} P<0.01 ;{ }^{* * *} P<0.001$. Statistical significance was judged as $P<0.05$. 
Table 9. Metabolism of formononetin and daidzein $(\mathrm{FDE}=$ formononetin + daidzein + equol) in dairy cows fed diets based on red clover-grass (ORG-SG), botanical diverse (ORG-LG), perennial ryegrass (CON-PR), or timothy (CON-TI) silage $(\mathrm{n}=4)$

\begin{tabular}{|c|c|c|c|c|c|c|}
\hline \multirow[b]{2}{*}{ Item } & \multicolumn{4}{|c|}{ Silage } & \multirow[b]{2}{*}{ SEM } & \multirow[b]{2}{*}{ Significance } \\
\hline & ORG-SG & ORG-LG & CON-PR & CON-TI & & \\
\hline Omasum (FDEo), mg/d & $5,506^{\mathrm{a}}$ & $194^{\mathrm{b}}$ & $44.5^{\mathrm{b}}$ & $16.6^{\mathrm{b}}$ & 182 & $* * *$ \\
\hline $\mathrm{FDEo} / \mathrm{FDEi}, \mathrm{mg} / \mathrm{mg}$ & $0.144^{\mathrm{a}}$ & $0.072^{\mathrm{b}}$ & $0.087^{\mathrm{b}}$ & $0.146^{\mathrm{a}}$ & 0.012 & $* *$ \\
\hline Feces (FDEf), mg/d & $1,267^{\mathrm{a}}$ & $46.8^{\mathrm{b}}$ & $15.0^{\mathrm{b}}$ & $5.83^{\mathrm{b}}$ & 79.7 & $* * *$ \\
\hline \multicolumn{7}{|l|}{ Intermediary } \\
\hline Milk (FDEm), mg/d & $7.63^{\mathrm{a}}$ & $0.94^{\mathrm{b}}$ & $0.28^{\mathrm{b}}$ & $0.10^{\mathrm{b}}$ & 0.513 & $* * *$ \\
\hline FDEm/FDEi, $\mu \mathrm{g} / \mathrm{mg}$ & 0.199 & 0.340 & 0.505 & 0.818 & 0.151 & NS \\
\hline FDEm/FDEo, $\mu \mathrm{g} / \mathrm{mg}$ & $1.38^{\mathrm{b}}$ & $4.83^{\mathrm{ab}}$ & $6.12^{\mathrm{a}}$ & $5.82^{\mathrm{ab}}$ & 1.12 & * \\
\hline
\end{tabular}

${ }^{\mathrm{a}, \mathrm{b}}$ Different letters within phytoestrogen indicate statistical difference within treatment and phase $(P<0.05)$.

${ }^{*} P<0.05 ;{ }^{* *} P<0.01 ;{ }^{* * *} P<0.001$. Statistical significance was judged as $P<0.05$.

The proportion of SMEE recovered in omasum from feed was higher $(P<0.05)$ for ORG-SG than for the pure grass silages. We detected no difference in omasal flow or in the proportion transferred from omasum to feces between the diets. The apparent recovery from feed to milk and from omasum to milk was higher $(P$ $<0.05)$ for ORG-LG than for CON-PR. Diet had no effect on the proportion transferred from feed to feces or from omasum to feces.

\section{DISCUSSION}

\section{Methodical Considerations in Flow Measurements}

The recoveries of the markers iNDF and $\mathrm{Cr}$ in feces in the current experiment were low (Adler et al., 2013), which may have affected our estimation of the omasal flow of digesta. As discussed by Adler et al. (2013), incomplete recovery may have been caused by different sources such as erroneous analysis of compounds in digesta and feces, inconsistent infusion rates, occasional leakage from cannulas, inaccurate amounts of feces collected, or unrepresentative sampling of omasal digesta. Corrections for fecal recovery assume an equal correction for fecal and omasal samples, which may not be correct. We concluded, therefore, that it was most correct to use the uncorrected omasal flow estimates.

\section{Feed Intake and Milk Yield}

Lower milk yield on CON-TI than on the other diets was likely due to slightly lower feed intake on CON-TI. Silage from CON-TI had, compared with the other silages, higher NDF and lower CP concentrations, which likely caused the lower feed intake (Mertens 2009).

\section{Concentrations of Phytoestrogens in Feeds}

A higher level of isoflavones in silage containing red clover was expected because red clover contains higher

Table 10. Metabolism of secoisolariciresinol and mateiresinol (SMEE $=$ secoisolariciresinol + matairesinol + enterodiol + enterolactone) in dairy cows fed diets based on red clover-grass (ORG-SG), botanical diverse (ORG-LG), perennial ryegrass (CON-PR), or timothy (CON-TI) silage $(\mathrm{n}=4)$

\begin{tabular}{|c|c|c|c|c|c|c|}
\hline Item & \multicolumn{4}{|c|}{ Silage } & SEM & Significance \\
\hline Intake (SMEEi), mg/d & $96.7^{\mathrm{c}}$ & $111^{\mathrm{bc}}$ & $150^{\mathrm{b}}$ & $213^{\mathrm{a}}$ & 11.7 & $* * *$ \\
\hline \multicolumn{7}{|l|}{ Digestive tract } \\
\hline Omasum (SMEEo), mg/d & 922 & 903 & 948 & 1086 & 127.6 & NS \\
\hline SMEEo/SMEEi, mg/mg & $9.58^{\mathrm{a}}$ & $7.98^{\mathrm{ab}}$ & $6.38^{\mathrm{b}}$ & $5.15^{\mathrm{b}}$ & 0.706 & $*$ \\
\hline Feces (SMEEf), mg/d & 602 & 592 & 752 & 897 & 94.8 & NS \\
\hline \multicolumn{7}{|l|}{ Intermediary } \\
\hline Milk (SMEEm), $\mu \mathrm{g} / \mathrm{d}$ & $394^{\mathrm{b}}$ & $808^{\mathrm{a}}$ & $471^{\mathrm{ab}}$ & $828^{\mathrm{a}}$ & 129.9 & $*$ \\
\hline SMEEm/SMEEi, $\mu \mathrm{g} / \mathrm{mg}$ & $4.06^{\mathrm{ab}}$ & $7.19^{\mathrm{a}}$ & $3.17^{\mathrm{b}}$ & $3.81^{\mathrm{ab}}$ & 0.86 & $*$ \\
\hline SMEEm/SMEEo, $\mu \mathrm{g} / \mathrm{mg}$ & $0.43^{\mathrm{b}}$ & $0.87^{\mathrm{a}}$ & $0.52^{\mathrm{ab}}$ & $0.77^{\mathrm{ab}}$ & 0.099 & $*$ \\
\hline
\end{tabular}

${ }^{\mathrm{a}-\mathrm{c}}$ Different letters within phytoestrogen indicate statistical difference within treatment and phase $(P<0.05)$.

${ }^{*} P<0.05$; ${ }^{* * *} P<0.001$. 
concentrations of isoflavones than grasses (Saloniemi et al., 1995; Wu et al., 2003; Mustonen et al., 2009). The total concentration of isoflavones and the distribution between the different isoflavones in ORG-SG was similar to the concentrations found in red clover grass silage (Steinshamn et al., 2008; Höjer et al., 2012), except for biochanin A, which was about $33 \%(0.7 \mathrm{~g} / \mathrm{kg}$ of DM) lower in the present study. The concentrations of biochanin A, genistein, formononetin, and daidzein in ORG-SG were 40 to $70 \%$ lower than when pure red clover silage was used (Mustonen et al., 2009). The concentrations of phytoestrogens in ORG-LG were similar to those found by Andersen et al. (2009b) in grass white clover silage. Differences between studies in forage contents of phytoestrogens were expected because environmental and agronomic factors have a strong effect on the concentration of phytoestrogens in plants (Sivesind and Seguin, 2005). The concentrations of phytoestrogens also increase during the ensiling process (Sarelli et al., 2003).

Secoisolariciresinol was the predominant lignan in all silages, consistent with other studies (Steinshamn et al., 2008; Höjer et al., 2012). Higher contents of secoisolariciresinol compared with matairesinol may be because secoisolariciresinol is an intermediate in the synthesis of matairesinol (Dixon, 2004). The concentrations of lignans were higher in all silages than in the barley-based concentrate in the current study. This supports the suggestion from Steinshamn et al. (2008) that forage is more important than cereal grains in concentrates for the intake of secoisolariciresinol and matairesinol.

Low concentrations of coumestrol in silages were expected and in accordance with the results reported in previous studies (Steinshamn et al., 2008; Andersen et al., 2009b). The higher concentration of coumestrol in ORG-LG than in ORG-SG was in agreement with Steinshamn et al. (2008), who found a higher concentration of coumestrol in white clover grass silage than in red clover grass silage. However, species other than white clover probably also contributed to the difference between ORG-LG and ORG-SG in the present study.

\section{Metabolism of Phytoestrogens}

Rumen Metabolism of Phytoestrogens. The major metabolic transformation of isoflavones is performed by rumen microbes (Nilsson et al., 1967; Batterham et al., 1971), and a high degree of transformation in the rumen was expected. Only 0 to $9 \%$ of daily biochanin A and genistein intake and 7 to $16 \%$ of the daily formononetin and daidzein intake were found in the omasum. This shows that extensive metabolism of isoflavones occurs in the rumen, and the degree of conversion was similar to that observed in a study in sheep in which no biochanin A or genistein were found but $12 \%$ of formononetin and daidzein were transferred from intake to abomasum (Shutt et al., 1970). For biochanin A and genistein, the proportion transferred from feed to omasum decreased with increasing intake. Rumen microbes adapt to the content of phytoestrogens in the feed and will become more efficient in metabolizing phytoestrogens over time. After 6 to $10 \mathrm{~d}$, rumen microbes adapt to the content of phytoestrogens in the feed, and biochanin A and genistein will be almost completely metabolized to para-ethyl phenol and organic acids without estrogenic effect (Shutt et al., 1970; Shutt, 1976; Seested et al., 2000). A slower metabolism with decreasing intake could be due to a lesser degree of adaptation. The same was partially shown for formononetin, daidzein, and equol, with the lowest metabolism for the CON-TI diet, and an increasing metabolism with increasing intake. The ORG-SG silage differed from this, which may be due to limiting factors in microbial metabolism in reticulo-rumen with a high concentration of precursors. An in vitro study with incubation of formononetin and biochanin A in bovine rumen fluid showed that the half-life was $4.3 \mathrm{~h}$ for formononetin, $9.3 \mathrm{~h}$ for daidzein, $3.9 \mathrm{~h}$ for biochanin $\mathrm{A}$, and $5.5 \mathrm{~h}$ for genistein (Dickinson et al., 1988). A longer half-life for formononetin and daidzein could explain why a higher percentage of those isoflavones, including equol, passed to the omasum than of biochanin A and genistein.

The content of lignans in the omasum and the excreted amounts of lignans were many times higher than the intake of secoisolariciresinol and matairesinol. This indicates that plant lignans other than the 2 analyzed were present in the feed and subsequently metabolized to enterodiol and enterolactone in the digestive tract. In an in vitro experiment of lignan metabolism in human fecal inoculum, Heinonen et al. (2001) showed that syringaresinol, pinoresinol, lariciresinol, arctigenin, and 7-hydroxymatairesinol are precursors for enterodiol and enterolactone. Pinoresinol and lariciresinol are precursors in the biosynthesis of secoisolariciresinol and matairesinol, and the intestinal microbial metabolism of pinoresinol seems to occur in a similar way, with lariciresinol and secoisolariciresinol as intermediates (Heinonen et al., 2001; Dixon, 2004). To our knowledge, these mammalian lignan precursors have not been analyzed in forages or silage but they are found in many vegetable crops (Milder et al., 2005). It is known that lignans are mainly found in the fiber layers in plants, where they form building blocks for the formation of lignin (Ayres and Loike, 1990). Begum et al. (2004) showed, in their experiment with rats, that lignin is a precursor for lignans. Thus, it could be expected that diets with the highest concentration of NDF would also result in the highest excretion of lignans. In the pres- 
ent study, CON-TI had highest intake of NDF, highest content of lignans in digesta passing to the omasum, and highest amounts excreted.

Omasal Flow of Phytoestrogens. To our knowledge, in vivo rumen metabolism of phytoestrogen and the passage of phytoestrogens to the omasum have not previously been reported in dairy cows. Most of the phytoestrogens hydrolyzed and most of the mammalian lignans formed in the rumen are likely absorbed in the rumen. However, a small portion of lignans passes to the omasum and further into the digestive tract. Equol was the dominating isoflavonoid in the digesta on all diets, consistent with a previous experiment in sheep (Shutt et al., 1970). Dickinson et al. (1988) incubated formononetin in bovine rumen fluid and found that a 24-h incubation resulted in almost complete demethylation of formononetin to daidzein and rapid conversion of daidzein to equol. The passage of formononetin to the omasum may be due to escape when the DM passage rate out of the rumen is higher than the metabolism rate of formononetin. Another possible explanation could be limited demethylation of formononetin to daidzein.

Enterolactone was the dominating lignan in omasal digesta, followed by enterodiol for all diets. This is in accordance with the results of Côrtes et al. (2008) who, in an in vitro experiment, found that enterolactone is the main mammalian lignan metabolized from secoisolariciresinol by rumen microbiota.

Equol followed mainly the LP when passing to the omasum, whereas the lignans enterolactone and enterodiol followed, to a large extent, the fluid particle flow. This was unexpected as isoflavones are found in cell vacuoles (Aoki et al., 2000) and are water soluble. Therefore their metabolite, equol, would most likely be found in the fluid phase. In sheep, Shutt et al. (1970) found no equol in rumen large particle digesta collected from sheep fed red clover, only in rumen liquid. An explanation for this discrepancy between the present study and Shutt et al. (1970) could be that a large part of the equol in the rumen fluid phase is absorbed in the rumen or metabolized to other compounds, and the small amounts passing to the omasum are located inside or nearby rumen microbes attached to particles. As lignan is found associated with plant fibers (Ayres and Loike, 1990) and lignin is a precursor for lignans (Begum et al., 2004), it is likely that the mammalian lignans in omasal digesta are located near fibers or near microbes that ferment fiber. For further studies, rumen microbes should be isolated and analyzed for phytoestrogens to determine whether mammalian phytoestrogens are located inside microbes or follow plant residues.

Metabolism of Phytoestrogens in the Intestines. The daily fecal excretion of isoflavones was lower than the amount passing to the omasum, indicating that isoflavones were further metabolized in the omasum (Lundh, 1990) or absorbed in the intestines. This would imply that the intestinal metabolism or absorption of isoflavones may have been overestimated in the present study. About $25 \%$ of the omasal flow of equol and its precursors was recovered in feces. Although our analysis of urine was not validated, the figures indicate for all diets - except for CON-TI, where the intake of isoflavones was very low - that feces was the main route of excretion of equol and its precursors and more important than urine and milk. Shutt et al. (1970) found that 16 times more equol was excreted in urine than in feces in sheep fed red clover. Tucker et al. (2010), on the other hand, found that excretion in feces was the main route, and about 30 times more equol was excreted in feces than in urine in heifers fed red clover. On ORG-SG, the excretion of FDE was about 3 times higher in feces than in urine. These results indicate that fundamental differences exist between sheep and cattle in the metabolism of isoflavones. Lundh (1990) found much lower conjugation capacity in the epithelial tissue of the gastrointestinal tissue from cows compared with sheep, which may explain why less equol is absorbed from the rumen of cattle than of sheep and more equol is thereby passing through the digestive tract in cattle than in sheep.

Metabolism of the plant lignans secoisolariciresinol and matairesinol was higher in the rumen than in the intestines and, on average, $74 \%$ of the omasal flow of secoisolariciresinol and matairesinol and the mammalian lignans enterodiol and enterolactone were excreted in the feces. This supports Gagnon et al. (2009a), who found that the main site of metabolism of flax lignans in dairy cows was the rumen when comparing flax hulls administered in either the rumen or the abomasum. Net production of enterodiol for CON-PR and CON-TI in the intestines was expected due to previous findings, although enterolactone was the predominant lignan excreted in feces (Côrtes et al., 2008). Côrtes et al. (2008) found higher net production of enterolactone than of enterodiol when flax seed and hulls were incubated with rumen microbes, whereas fecal microbes had higher net production of enterodiol than enterolactone. This suggests that the main mammalian lignan produced by fecal microbes from secoisolariciresinol-diglucoside is enterodiol. Our results for CON-PR and CON-TI support this, but we have no explanation for the decrease in enterodiol on ORG-SG and ORG-LG. The difference in location and binding of phytoestrogens in plant material may explain why relatively more of the omasal flow of lignans (on average $0.74 \mathrm{mg} / \mathrm{mg}$ for SMEE) than isoflavones (on average $0.29 \mathrm{mg} / \mathrm{mg}$ for FDE) was not absorbed but excreted in feces. 


\section{Recovery in Milk}

Because of the high gastrointestinal metabolism of isoflavones, only minor modifications of milk isoflavone concentration are expected. However, except for prunetin, milk content of isoflavones increased with intake for all isoflavones analyzed and in accordance with previous findings (Steinshamn et al., 2008; Andersen et al., 2009b; Mustonen et al., 2009). The dietary effect on milk excretion of lignans was not directly linked to the intake of the analyzed lignans. Therefore, it seems to be less straightforward to manipulate milk lignan content with silage botanical composition. However, as there are obviously other plant lignans that are more important precursors of enterolactone and enterodiol than secoisolariciresinol and matairesinol, it is not possible to be conclusive. More research is needed to find these precursors lignans.

Equol was the predominant isoflavone in milk from all diets and is also one of the most investigated isoflavones. The concentration of equol in milk from ORG-SG was similar to that found in other feeding experiments with red clover-grass silages (Steinshamn et al., 2008; Mustonen et al., 2009), although much higher concentrations have been observed with similar diets (Höjer et al., 2012). The concentrations of equol in milk from CON-PR and CON-TI were comparable to those found in conventionally produced retail milk (Antignac et al., 2004; Hoikkala et al., 2007) and that of ORG-LG was similar to milk produced on white clover grass-based diets (Steinshamn et al., 2008).

The apparent recovery from feed to milk of formononetin, daidzein, and equol on ORG-LG was lower than expected from previous studies with similar intakes (Steinshamn et al., 2008; Andersen et al., 2009b). This applies also to biochanin A and genistein when cows were fed CON-TI, in which the recoveries were lower than those found by Andersen et al. (2009b) at similar intake. Milk production level was low in the current study, which may have affected the recovery of phytoestrogens from feed to milk. Apparent recovery of isoflavones from feed to milk was highest for the diets containing the lowest amounts of isoflavones, which is consistent with other studies (Steinshamn et al., 2008; Andersen et al., 2009b; Höjer et al., 2012).

Concentrations of enterolactone in milk from CON-TI and ORG-LG silages were similar to the level reported in previous studies (Antignac et al., 2004; Gagnon et al., 2009b), and the levels of enterolactone in milk from ORG-SG and CON-PR were similar to the levels Steinshamn et al. (2008) observed in milk from cows fed white clover-grass or red clover-grass silages. Apparent recovery of lignans in milk was, even with an intake at the same level, lower than found by Steinshamn et al. (2008) and Andersen et al. (2009b). The likely reason for this is that the unknown plant precursors for enterodiol and enterolactone exist in various amounts. In addition, the milk production level was lower in the current study than in the other studies.

The decreasing apparent recovery of isoflavones from feed to milk with increasing intake may be due to several factors. Steinshamn et al. (2008) suggested that the metabolism in the gastrointestinal tract and the reconjugation before blood transport and secretion in the udder could be rate limiting, and the cells in mammary gland might only be permeable to estrogenic compounds. The results from the present study, with a high degree of metabolism in the rumen and gastrointestinal tract, indicate that the limiting factors are reconjugation and absorption through the rumen and intestinal wall. Enzymatic reactions, like conjugation of phytoestrogens, follow Michaelis-Menten saturation kinetics, with a diminishing increase in reaction rate with increasing substrate. Active transport of substrates from blood to mammary tissue usually follows the same kinetics (Shennan and Peaker, 2000), so it is possible that both reconjugation and secretion in cells in the udder could be limiting factors.

Using the daily per capita milk consumption of 305 and $185 \mathrm{~g}$ in the United States and Norway (FAOSTAT, 2014), intake of milk produced on ORGSG would result in a daily intake of 143 and $87 \mu \mathrm{g}$ of phytoestrogens, respectively. This is low compared with the calculated daily intake of 2,439 and $736 \mu \mathrm{g}$ of phytoestrogens by women in Norway and the United States, respectively (de Kleijn et al., 2001; Zamora-Ros et al., 2012). However, consumption of milk from ORGSG rather than milk from the grass-based diets would increase the intake of milk phytoestrogens 9-fold, an effect that should not be underestimated. The implications of such an elevated intake of phytoestrogens on human health are yet to be elucidated. Total fecal and urinary excretion was 2.5-fold higher on ORG-SG than on the grass-based diets, and the environmental implications of such an increase warrants further study as phytoestrogen metabolites in feces and urine retain estrogenic activity (Tucker et al., 2010).

\section{CONCLUSIONS}

Phytoestrogens were extensively metabolized in the rumen to mammalian phytoestrogens and unknown compounds. The metabolism of isoflavones depended on intake, with the lowest recovery in the omasum found for diets with the highest concentration and intake of isoflavones. Isoflavones mainly passed to the omasum with large particles, whereas mammalian lignans were evenly distributed between phases when passing to the 
omasum. Total flow of mammalian lignans, from feed to omasum and to feces, was higher than the intake of measured plant lignans. This was probably due to a high amount of unknown precursor lignans in the diet. The phytoestrogens were further metabolized in the intestines but to a lesser degree than in the rumen. The main route of excretion of both isoflavonoids and lignans was through feces. The concentration of isoflavones in milk can be manipulated through diet because the concentration of isoflavones in milk increased with increasing intake. However, apparent recovery of isoflavones in milk decreased with increasing intake. Intermediary factors appear to limit full transition to milk.

\section{ACKNOWLEDGMENTS}

The authors thank the Coordination of European Transnational Research in Organic Food and Farming (CORE) Organic Funding Body Network (Tjele, Denmark), the Swedish Research Council (Formas, Stockholm), the Research Council of Norway (Oslo), and the Danish Council for Independent Research (Copenhagen) for funding this research project and to TINE SA for grant supporting Kari Marie Njaastad's MSc thesis.

\section{REFERENCES}

AACC (American Association of Cereal Chemists). 2000. Method 7611 in Approved Methods. 10th ed. American Association of Cereal Chemists, Washington, DC.

Adler, S. A., S. K. Jensen, E. Thuen, A.-M. Gustavsson, O. M. Harstad, and H. Steinshamn. 2013. Effect of silage botanical composition on ruminal biohydrogenation and transfer of fatty acids to milk in dairy cows. J. Dairy Sci. 96:1135-1147. http://dx.doi. org/10.3168/jds.2012-5757.

Adler, S. A., S. Purup, J. Hansen-Møller, E. Thuen, A. M. Gustavsson, and H. Steinshamn. 2014. Phyto-oestrogens and their metabolites in milk produced on two pastures with different botanical compositions. Livest. Sci. 163:62-68. http://dx.doi.org/10.1016/j. livsci.2014.02.006.

Ahvenjärvi, S., A. Vanhatalo, P. Huhtanen, and T. Varvikko. 2000. Determination of reticulo-rumen and whole-stomach digestion in lactating cows by omasal canal or duodenal sampling. Br. J. Nutr. 83:67-77. http://dx.doi.org/10.1017/S0007114500000106.

Åkerlind, M., M. Weisbjerg, T. Eriksson, R. Tøgersen, P. Udén, B. L. Olafsson, O. M. Harstad, and H. Volden. 2011. Feed analyses and digestion method. Pages 41-54 in NorFor-The Nordic Feed Evaluation System. H. Volden, ed. Wageningen Academic Publishers, Wageningen, the Netherlands.

Andersen, C., T. S. Nielsen, S. Purup, T. Kristensen, J. Eriksen, K. Søegaard, J. Sørensen, and X. C. Fretté. 2009a. Phyto-oestrogens in herbage and milk from cows grazing white clover, red clover, lucerne or chicory-rich pastures. Animal 3:1189-1195. http:// dx.doi.org/10.1017/S1751731109004613.

Andersen, C., M. R. Weisbjerg, M. Hansen, and K. Sejrsen. 2009b. Effect of forage on the content of phyto-oestrogens in bovine milk. Animal 3:617-622. http://dx.doi.org/10.1017/S1751731108003698.

Antignac, J. P., R. Cariou, B. Le Bizec, and F. André. 2004. New data regarding phytoestrogens content in bovine milk. Food Chem. 87:275-281. http://dx.doi.org/10.1016/j.foodchem.2003.12.013.

AOAC. 1990. Official Methods of Analysis. 15th ed. Association of Official Analytical Chemists, Washington, DC.
Aoki, T., T. Akashi, and S. Ayabe. 2000. Flavonoids of leguminous plants: Structure, biological activity, and biosynthesis. J. Plant Res. 113:475-488. http://dx.doi.org/10.1007/PL00013958.

Armentano, L. E., and R. W. Russell. 1985. Method for calculating digesta flow and apparent absorption of nutrients from nonrepresentative samples of digesta. J. Dairy Sci. 68:3067-3070. http:// dx.doi.org/10.3168/jds.S0022-0302(85)81204-2.

Axelson, M., J. Sjövall, B. E. Gustafsson, and K. D. R. Setchell. 1982. Origin of lignans in mammals and identification of a precursor from plants. Nature 298:659-660. http://dx.doi.org/10.1038/298659a0.

Ayres, D. C., and J. D. Loike. 1990. Lignans. Chemical, Biological and Clinical Properties. Chemistry and Pharmacology of Natural Products. Cambridge University Press, Cambridge, NY

Batterham, T. J., D. A. Shutt, A. W. Braden, and H. J. Tweeddale. 1971. Metabolism of intraruminally administered $\left[4-{ }^{14} \mathrm{C}\right]$ formononetic and $\left[4-{ }^{14} \mathrm{C}\right]$ biochanin $\mathrm{A}$ in sheep. Aust. J. Agric. Res. 22:131-138. http://dx.doi.org/10.1071/AR9710131.

Begum, A. N., C. Nicolle, I. Mila, C. Lapierre, K. Nagano, K. Fukushima, S.-M. Heinonen, H. Adlercreutz, C. Rémésy, and A. Scalbert. 2004. Dietary lignins are precursors of mammalian lignans in rats. J. Nutr. 134:120-127.

Bennetts, H. W., E. J. Underwood, and F. L. Shier. 1946. A specific breeding problem of sheep on subterranean clover pastures in Western Australia. Aust. Vet. J. 22:2-12. http://dx.doi. org/10.1111/j.1751-0813.1946.tb15473.x.

Borriello, S. P., K. D. R. Setchell, M. Axelson, and A. M. Lawson. 1985. Production and metabolism of lignans by the human fecal flora. J. Appl. Bacteriol. 58:37-43. http://dx.doi. org/10.1111/j.1365-2672.1985.tb01427.x.

Bouker, K. B., and L. Hilakivi-Clarke. 2000. Genistein: Does it prevent or promote breast cancer? Environ. Health Perspect. 108:701708

Cassidy, A., B. Hanley, and R. M. Lamulela-Raventos. 2000. Isoflavones, lignans and stilbenes-Origins, metabolism and potential importance to human health. J. Sci. Food Agric. 80:1044-1062.

Côrtes, C., N. Gagnon, C. Benchaar, D. da Silva, G. T. D. Santos, and H. V. Petit. 2008. In vitro metabolism of flax lignans by ruminal and faecal microbiota of dairy cows. J. Appl. Microbiol. 105:15851594. http://dx.doi.org/10.1111/j.1365-2672.2008.03922.x.

COT (Committee on Toxicity of Chemicals in Food, Consumer Products and the Environment). 2003. Phytoestrogens and health. Food Standards Agency, Department of Health, London, UK.

De Assis, S., and L. Hilakivi-Clarke. 2006. Timing of dietary estrogenic exposures and breast cancer risk. Ann. N. Y. Acad. Sci. 1089:14-35. http://dx.doi.org/10.1196/annals.1386.039.

de Kleijn, M. J. J., Y. T. van der Schouw, P. W. F. Wilson, H. Adlercreutz, W. Mazur, D. E. Grobbee, and P. F. Jacques. 2001. Intake of dietary phytoestrogens is low in postmenopausal women in the United States: The Framingham Study. J. Nutr. 131:1826-1832.

Dickinson, J. M., G. R. Smith, R. D. Randel, and I. J. Pemberton. 1988. In vitro metabolism of formononetin and biochanin A in bovine rumen fluid. J. Anim. Sci. 66:1969-1973.

Dixon, R. A. 2004. Phytoestrogens. Annu. Rev. Plant Biol. 55:225261.

European Union. 2007. Council Regulation (EC) No 834/2007 of 28 June 2007 on organic production and labelling of organic products and repealing Regulation (EEC) No 2092/91. Off. J. Eur. Union L 189:1-23.

Faichney, G. J. 1975. The use of markers to partition digestion within the gastro-intestinal tract of ruminants. Pages 277-291 in Digestion and Metabolism in the Ruminant. I. W. McDonald and A. C. I. Warner, ed. University of New England Publishing Unit, Armidale, Australia.

FAOSTAT (Food and Agriculture Organization of the United Nations, Statistics Division). 2014. Food supply-Livestock and fish primary equivalent. Rome, Italy. Accessed July 2014. http://faostat3. fao.org/faostat-gateway/go/to/download/C/CL/E.

Gagnon, N., C. Côrtes, D. da Silva, R. Kazama, C. Benchaar, G. dos Santos, L. Zeoula, and H. Petit. 2009a. Ruminal metabolism of flaxseed (Linum usitatissimum) lignans to the mammalian lignan enterolactone and its concentration in ruminal fluid, plasma, urine 
and milk of dairy cows. Br. J. Nutr. 102:1015-1023. http:// dx.doi.org/10.1017/S0007114509344104.

Gagnon, N., C. Côrtes, and H. Petit. 2009b. Weekly excretion of the mammalian lignan enterolactone in milk of dairy cows fed flaxseed meal. J. Dairy Res. 76:455-458. http://dx.doi.org/10.1017/ S0022029909990082.

Heinonen, S., T. Nurmi, K. Liukkonen, K. Poutanen, K. Wahala, T. Deyama, S. Nishibe, and H. Adlercreutz. 2001. In vitro metabolism of plant lignans: New precursors of mammalian lignans enterolactone and enterodiol. J. Agric. Food Chem. 49:3178-3186. http://dx.doi.org/10.1021/jf010038a.

Hoikkala, A., E. Mustonen, I. Saastamoinen, T. Jokela, J. Taponen, H. Saloniemi, and K. Wahala. 2007. High levels of equol in organic skimmed Finnish cow milk. Mol. Nutr. Food Res. 51:782-786. http://dx.doi.org/10.1002/mnfr.200600222.

Höjer, A., S. Adler, S. Purup, J. Hansen-Möller, K. Martinsson, H. Steinshamn, and A. M. Gustavsson. 2012. Effects of feeding dairy cows different legume-grass silages on milk phytoestrogen concentration. J. Dairy Sci. 95:4526-4540. http://dx.doi.org/10.3168/ jds.2011-5226.

Huhtanen, P., P. G. Brotz, and L. D. Satter. 1997. Omasal sampling technique for assessing fermentative digestion in the forestomach of dairy cows. J. Anim. Sci. 75:1380-1392.

Lindner, H. R. 1967. Study of the fate of phyto-oestrogens in the sheep by determination of isoflavones and coumestrol in the plasma and adipose tissue. Aust. J. Agric. Res. 18:315-333. http://dx.doi. org/10.1071/AR9670305.

Lundh, T. J. O. 1990. Conjugation of the plant estrogens formononetin and daidzein and their metabolite equol by gastrointestinal epithelium from cattle and sheep. J. Agric. Food Chem. 38:1012-1016. http://dx.doi.org/10.1021/jf00094a021.

Mazur, W. 1998. Phytoestrogen content in foods. Baillieres Clin. Endocrinol. Metab. 12:729-742. http://dx.doi.org/10.1016/S0950351X (98)80013-X

Mendez, M. A., M. S. Anthony, and L. Arab. 2002. Soy-based formulae and infant growth and development: A review. J. Nutr. $132: 2127-2130$.

Mertens, D. R. 2002. Gravimetric determination of amylase-treated neutral detergent fiber in feeds with refluxing in beakers or crucibles: Collaborative study. J. AOAC Int. 85:1217-1240.

Mertens, D. R. 2009. Impact of NDF content and digestibility on dairy cow performance. Adv. Dairy Technol. 21:191-201.

Miksicek, R. J. 1995. Estrogenic flavonoids: Structural requirements for biological activity. Proc. Soc. Exp. Biol. Med. 208:44-50.

Milder, I. E., I. C. A. Arts, B. van de Putte, D. P. Venema, and P. C. H. Hollman. 2005. Lignan contents of Dutch plant foods: A database including lariciresinol, pinoresinol, secoisolariciresinol and matairesinol. Br. J. Nutr. 93:393-402. http://dx.doi.org/10.1079/ BJN20051371.

Mustonen, E. A., M. Tuori, I. Saastamoinen, J. Taponen, K. Wähälä, H. Saloniemi, and A. Vanhatalo. 2009. Equol in milk of dairy cows is derived from forage legumes such as red clover. Br. J. Nutr. 102:1552-1556. http://dx.doi.org/10.1017/S0007114509990857.

Nilsson, A.. J. L. Hill, and H. Lloyd Davies. 1967. An in vitro study of formononetin and biochanin A metabolism in rumen fluid from sheep. Biochim. Biophys. Acta 148:92-98. http://dx.doi. org/10.1016/0304-4165(67)90282-6.

Petit, H. V., and N. Gagnon. 2009. Milk concentrations of the mammalian lignans enterolactone and enterodiol, milk production, and whole tract digestibility of dairy cows fed diets containing different concentrations of flaxseed meal. Anim. Feed Sci. Technol. 152:103-111. http://dx.doi.org/10.1016/j.anifeedsci.2009.04.004.

Petit, H. V., N. Gagnon, P. S. Mir, R. Cao, and S. Cui. 2009. Milk concentration of the mammalian lignan enterolactone, milk production, milk fatty acid profile, and digestibility in dairy cows fed diets containing whole flaxseed or flaxseed meal. J. Dairy Res. 76:257-264. http://dx.doi.org/10.1017/S0022029909003999.

Saloniemi, H., K. Wahala, P. Nykanenkurki, K. Kallela, and I. Saastamoinen. 1995. Phytoestrogen content and estrogenic effect of legume fodder. Proc. Soc. Exp. Biol. Med. 208:13-17. http:// dx.doi.org/10.3181/00379727-208-43825.
Sarelli, L., M. Tuori, I. Saastamoinen, L. Syrjala-Qvist, and H. Saloniemi. 2003. Phytoestrogen content of birdsfoot trefoil and red clover: Effects of growth stage and ensiling method. Acta Agric. Scand. A Anim. Sci. 53:58-63. http://dx.doi. org/10.1080/09064700310002053.

SAS Institute. 2009. SAS/STAT User's Guide. Version 9.2. SAS Institute Inc., Cary, NC.

Seested, S., P. Nørgaard, and H. Ranvig. 2000. Factors affecting the phytoestrogen content of clover and alfalfa and its influence on the female fertility in ruminants. Dansk Veterinærtidsskrift. 83:6-12.

Shennan, D. B., and M. Peaker. 2000. Transport of milk constituents by the mammary gland. Physiol. Rev. 80:925-951.

Shutt, D., R. Weston, and J. Hogan. 1970. Quantitative aspects of phytooestrogen metabolism in sheep fed on subterranean clover (Trifolium subterraneum cultivar clare) or red clover (Trifolium pratense). Aust. J. Agric. Res. 21:713-722.

Shutt, D. A. 1976. The effects of plant oestrogens on animal reproduction. Endeavour 35:110-113.

Shutt, D. A., and A. W. Braden. 1968. The significance of equol in relation to the oestrogenic responses in sheep ingesting clover with a high formononetin content. Aust. J. Agric. Res. 19:545-553. http://dx.doi.org/10.1071/AR9680545.

Sirtori, C. R., A. Arnoldi, and S. K. Johnson. 2005. Phytoestrogens: End of a tale? Ann. Med. 37:423-438. http://dx.doi org $/ 10.1080 / 07853890510044586$.

Sivesind, E., and P. Seguin. 2005. Effects of the environment, cultivar, maturity, and preservation method on red clover isoflavone concentration. J. Agric. Food Chem. 53:6397-6402.

Steinshamn, H., S. Purup, E. Thuen, and J. Hansen-Møller. 2008. Effects of clover-grass silages and concentrate supplementation on the content of phytoestrogens in dairy cow milk. J. Dairy Sci. 91:2715-2725. http://dx.doi.org/10.3168/jds.2007-0857.

Tham, D. M., C. D. Gardner, and W. L. Haskell. 1998. Potential health benefits of dietary phytoestrogens: A review of the clinical, epidemiological, and mechanistic evidence. J. Clin. Endocrinol Metab. 83:2223-2235. http://dx.doi.org/10.1210/jcem.83.7.4752.

Třináctý, J., L. Křrižová, V. Schulzová, J. Hajšlová, and O. Hanuš. 2009. The effect of feeding soybean-derived phytoestrogens on their concentration in plasma and milk of lactating dairy cows. Arch. Anim. Nutr. 63:219-229. http://dx.doi.org/10.1080/17450390902859739

Tucker, H. A., K. F. Knowlton, M. T. Meyer, W. O. Khunjar, and N. G. Love. 2010. Effect of diet on fecal and urinary estrogenic activity. J. Dairy Sci. 93:2088-2094. http://dx.doi.org/10.3168/ jds.2009-2657.

Tuohy, P. G. 2003. Review article: Soy infant formula and phytoestrogens. J. Paediatr. Child Health 39:401-405. http://dx.doi. org/10.1046/j.1440-1754.2003.00178.x.

Wu, Q. L., M. F. Wang, and J. E. Simon. 2003. Determination of isoflavones in red clover and related species by high-performance liquid chromatography combined with ultraviolet and mass spectrometric detection. J. Chromatogr. A 1016:195-209. http:// dx.doi.org/10.1016/j.chroma.2003.08.001.

Zamora-Ros, R., V. Knaze, L. Luján-Barroso, G. G. C. Kuhnle, A. A. Mulligan, M. Touillaud, N. Slimani, I. Romieu, N. Powell, R. Tumino, P. H. M. Peeters, M. S. de Magistris, F. Ricceri, E. Sonestedt, I. Drake, A. Hjartåker, G. Skie, T. Mouw, P. A. Wark, D. Romaguera, H. B. Bueno-de-Mesquita, M. Ros, E. Molina, S. Sieri, J. R. Quirós, J. M. Huerta, A. Tjønneland, J. Halkjær, G. Masala, B. Teucher, R. Kaas, R. C. Travis, V. Dilis, V. Benetou, A. Trichopoulou, P. Amiano, E. Ardanaz, H. Boeing, J. Förster, F. Clavel-Chapelon, G. Fagherazzi, F. Perquier, G. Johansson, I. Johansson, A. Cassidy, K. Overvad, and C. A. González. 2012. Dietary intakes and food sources of phytoestrogens in the European Prospective Investigation into Cancer and Nutrition (EPIC) 24hour dietary recall cohort. Eur. J. Clin. Nutr. 66:932-941. http:// dx.doi.org/10.1038/ejcn.2012.36.

Zung, A., R. Reifen, Z. Keem, and Z. Zadik. 2001. Phytoestrogens The pediatric perspective. J. Pediatr. Gastroenterol. Nutr. $33: 112-118$ 